\title{
Growth Response of Clarias gariepinus Post Fingerlings Fed Various Dietary Protein and Digestible Energy Levels
}

\author{
B. S. Aliu ${ }^{1 *}$ and J. T. Otuagomah ${ }^{1}$ \\ ${ }^{1}$ Department of Fisheries, Faculty of Agriculture, University of Benin, P.M.B. 1154, Benin City, Nigeria.
}

Authors' contributions

This work was carried out in collaboration between both authors. Author BSA designed the study and wrote the draft of the manuscript. Author JTO performed the laboratory experiments and statistical analysis under the supervision of author BSA. Both authors read and approved the final manuscript.

Article Information

DOI: $10.9734 / J A B B / 2017 / 31608$

Editor(s):

(1) Cosmas Nathanailides, Dept. Fisheries and Aquaculture Technology, Technological Educational Institute of West Greece,

Greece.

Reviewers:

(1) A. M. ORIRE, Federal University of Technology, Minna, Nigeria. (2) Hernández, David Roque, National University of the Northeast, Argentina.

(3) Oso, James Abayomi, Ekiti State University, Nigeria. Complete Peer review History: http://www.sciencedomain.org/review-history/18196

Original Research Article

Received $16^{\text {th }}$ January 2017

Accepted $13^{\text {th }}$ February 2017 Published 15 $5^{\text {th }}$ March 2017

\begin{abstract}
The purpose of this work was to determine the growth response of Clarias gariepinus post fingerlings to four protein level $(25 \%, 30 \%, 35 \%$ and $40 \%$ ) by two energy level (2800 and 3000 $\mathrm{Kcal} / \mathrm{kg}$ ) so as to be able to estimate the response of the various fish fed with the diets containing this varying protein and digestible energy levels, their growth performance and protein utilization. Eight experimental diets were formulated and used to feed the post fingerlings for a period of 70 days in three replicate for each treatment. The feed and fish carcasses were analyzed for proximate composition of the post fingerlings. Parameters such as Specific Growth Rate (SGR), weekly weight gain (WWG) as well as Percentage Weight gain (PEWG) recorded the best weight gain at a crude protein of $40 \%$ and Digestible energy $(\mathrm{kcal} / \mathrm{kg})$ DE of 3000 while the least value for weight gain was recorded at $30 \% \mathrm{CP}$ at $2800 \mathrm{DE}$. An increase in PEWG was recorded across the various crude protein levels except at 35\% CP and 40\% CP at 3000DE and 2800DE respectively. The feed with $30 \% \mathrm{CP}$ at 3000DE constantly maintained the fifth position and that with 35\% CP with 3000DE maintained the third position according to TWG, SGR, RWG and PEWG.
\end{abstract}


Keywords: Clariid catfish; Clarias gariepinus; fingerlings; optimum energy; protein levels; fish diet.

\section{INTRODUCTION}

Aquaculture requires optimization of nutrition to efficiently raise fish for food production. Nutrition have been reported by [1] to play a critical role in intensive aquaculture as it influences production cost and also fish growth, health and waste production. Fish nutrition is the study of nutrients and energy sources essential for fish health, growth and reproduction [2]. Fish requires high quality nutritionally balanced diet for growth and attainment of market size within the shortest possible time [3]. Catfish farming has continued to attract private sector initiative compared to earlier public or government-sponsored programmes [4]. Clarias gariepinus is regarded as a good prospect for Aquaculture due to its outstanding culture characteristics such as ability to adapt adverse environmental conditions, efficient utilization of various types of locally formulated fish feed, resistance to diseases, high economic potential and simple techniques in the propagation of their fingerlings [5].

The purpose of this study is to determine the growth and utilization of crude protein and digestible energy variation by $C$. gariepinus post fingerlings.

\section{MATERIALS AND METHODS}

Feeding trials were conducted to determine the optimum protein and digestible energy levels for the Clariid catfish post fingerings using $C$. gariepinus.

\subsection{Experimental Diets}

Eight (8) diets were used for the feeding trials. This experiment comprising of four protein levels $(25,30,35$ and $40 \% \mathrm{CP})$ by two energy levels (2800 and $3000 \mathrm{Kcal} / \mathrm{kg}$ ) diets. The layout of the dietary treatment is shown in Table 1.

Each diet constituted a treatment. The details of nutrient composition of feedstuffs of experimental diets and proximate analysis are shown in Table 2.

In preparing the diets, ingredients were milled, mixed and prepared as described by [6]. The milled ingredients were sieved through standard sieve Nos. 16 and 20 (maximum of $1.19 \mathrm{~mm}$ ). The homogenous feed mixes were processed into pellets or granules $(2 \mathrm{~mm})$ with gelatinized corn starch component as the binder. After preparation, pelleted diets were oven-dried at

Table 1. Gross composition of experimental diets (\%)

\begin{tabular}{lllllllll}
\hline Ingredients & \multicolumn{7}{c}{ Diets } \\
\cline { 2 - 10 } & $\mathbf{1}$ & $\mathbf{2}$ & $\mathbf{3}$ & $\mathbf{4}$ & $\mathbf{5}$ & $\mathbf{6}$ & $\mathbf{7}$ & $\mathbf{8}$ \\
\hline Yellow maize (9.5\% CP) & 24.79 & 22.29 & 19.79 & 17.79 & 20.44 & 17.44 & 13.44 & 10.94 \\
Fish meal (65.5\% CP) & 7.00 & 7.00 & 14.50 & 14.50 & 21.40 & 21.40 & 26.40 & 26.40 \\
Soyabean meal (44.0\% CP) & 16.77 & 16.77 & 18.77 & 18.77 & 20.20 & 20.20 & 24.20 & 24.20 \\
Brewer's yeast (50\% CP) & 12.77 & 12.77 & 14.77 & 14.77 & 16.40 & 16.40 & 18.10 & 18.10 \\
Wheat bran (12.5\% CP) & 27.58 & 27.58 & 22.58 & 22.58 & 14.10 & 14.10 & 14.40 & 14.10 \\
Palm oil & 7.63 & 10.13 & 6.13 & 8.13 & 4.00 & 7.00 & 0.00 & 2.50 \\
Bone meal & 3.00 & 3.00 & 3.00 & 3.00 & 3.00 & 3.00 & 3.00 & 3.00 \\
Vitamin premix & 0.40 & 0.40 & 0.40 & 0.40 & 0.40 & 0.40 & 0.40 & 0.40 \\
Vitamin E & 0.06 & 0.06 & 0.06 & 0.06 & 0.06 & 0.06 & 0.06 & 0.06 \\
\hline
\end{tabular}

Table 2. Proximate composition of experimental diets (on as-fed basis)

\begin{tabular}{lllllll}
\hline Diets & \%MC & \%ASH & \%EE(FAT) & \%FIBER & \%CP & \%NFE \\
\hline 1 & 12.29 & 2.14 & 23.45 & 2.52 & 16.33 & 43.27 \\
2 & 7.52 & 8.31 & 25.41 & 1.51 & 5.25 & 51.99 \\
3 & 12.23 & 2.01 & 22.43 & 4.53 & 31.50 & 27.30 \\
4 & 10.23 & 8.52 & 25.41 & 4.53 & 26.25 & 25.06 \\
5 & 10.23 & 8.12 & 27.11 & 1.52 & 8.75 & 44.27 \\
6 & 13.42 & 8.52 & 20.23 & 4.53 & 43.75 & 19.55 \\
7 & 13.41 & 2.13 & 20.21 & 1.23 & 45.20 & 17.81 \\
8 & 14.43 & 8.23 & 23.41 & 1.21 & 40.25 & 12.47 \\
\hline
\end{tabular}


$70^{\circ} \mathrm{C}$ for 24 hours. Feed samples were stored in polythene bags in cupboard at laboratory temperature. Dried granules of feed samples were taken for proximate analysis. All ingredients were locally sourced for the trial conducted.

There were four trials, one trial for each type of feed. Glass tank was used for the trials. Each tank was connected to a central aerator. Water supplied by the university of Benin Campus domestic water services was maintained at 35 litre mark/level throughout the experiment. Fingerings were fed test diets twice daily during daylight (9:30 am and 4:00 pm). At each time of feeding, animals were fed to satiation i.e. hand fed access to food, during which diet was provided in small amount at a time, so that the fish will eat nearly all the diet offered.

Water temperature was measured twice daily during feeding using thermometer. Dissolved oxygen (DO) was measured once a week using Winkler's method. Daily observations were made to detect any abnormality and fish mortality. Unconsumed diets and faecal wastes were removed by siphoning daily. Each trial lasted 70 days. Weight of fish per treatment and per replicate was recorded weekly. Weight of food consumed by fish was also recorded weekly for each replicate. In order to obtain the weights of the fish, fish were batch weighted in a dish containing pre-weighed water.

C. gariepinus post fingerlings were obtained from outdoor fish tanks of the Department of Fisheries, University of Benin, Benin city.

\subsection{Carcass Analysis}

All the diets and carcasses were subjected to proximate analysis at the end of the trials. Crude protein (N X 6.25) was determined by the microkjeldahl method and crude fibre (CF) was by the system based on acid-alkaline digestion. Lipids, ash and moisture were determined using standard methods set by [7] in triplicate.

\subsection{Growth and Nutrient Utilization Indices}

Weights of fish and feed consumption were obtained at weekly intervals. From the fish weights and feed consumption, the following were determined:

$$
\begin{aligned}
& \text { Weight gain }=W_{1}-W_{0}(g) \\
& \text { Relative Weight Gain }(R W G \%)=\left(W_{1}-W_{0}\right) / \\
& W_{0} \times 100(\%)
\end{aligned}
$$

$$
\begin{aligned}
& \text { Specific Growth Rate (SGR \%) }=\left\{\left(\ln \mathrm{W}_{1}-\ln \right.\right. \\
& \left.\left.\mathrm{W}_{0}\right) / \mathrm{T}\right\} \times 100(\% / \text { week })
\end{aligned}
$$

Where;

$$
\begin{aligned}
& \mathrm{W}_{0} \text { : mean initial weight }(\mathrm{g}) \\
& \mathrm{W}_{1} \text { : mean final weight }(\mathrm{g}) \\
& \mathrm{T} \text { : time in } 7 \text { days between weightings }
\end{aligned}
$$

Feed conversion ratio $(F C R)=$ feed intake $(\mathrm{g}) /$ wet weight gain $(\mathrm{g})$

Protein efficiency ratio $($ PER $)=$ weight gain $(\mathrm{g}) /$ protein intake (g)

Net protein utilization $(\mathrm{NPU})=\left\{\left(\mathrm{BP}_{1}-\mathrm{BP}_{0}\right) / \mathrm{CP}\right\}$ $\times 100$

Where;

$$
\begin{aligned}
& \mathrm{BP}_{0} \text { : Initial body protein content }(\mathrm{g}) \\
& \mathrm{BP}_{1} \text { : Final body protein content }(\mathrm{g}) \\
& \mathrm{CP} \text { : Protein intake }(\mathrm{g})
\end{aligned}
$$

\subsection{Statistical Analysis}

At the end of the experiments, recorded data were subjected to two-way ANOVA test using a Genstat software eight edition, 2005 package for statistical problems. All the means were compared at $5 \%$ level of probability with Duncan multiple range tests.

\section{RESULTS}

Table 3 shows the result recorded by $C$. gariepinus post fingerlings after 70 days feeding trial. The highest total weight gain was recorded at a CP level of $40 \%$ at $2800 \mathrm{DE}$ and was followed by $40 \% \mathrm{CP}$ at $3000 \mathrm{kcal} / \mathrm{kg} \mathrm{DE}$. The least weight gain was recorded at $30 \% \mathrm{CP}$ by $2800 \mathrm{DE}$. The results also showed that weight gain at $40 \% \mathrm{CP}$ and DE of $3000 \mathrm{kcal} / \mathrm{kg}$ and $2800 \mathrm{Kcal} / \mathrm{kg}$ were not significantly different but $35 \%$ CP with $3000 \mathrm{DE}$ are significantly different from all treatments as well as $30 \% \mathrm{CP}$ with $2800 \mathrm{DE}$. At $25 \%$ through all DE levels and $30 \%$ $\mathrm{CP}$ at $3000 \mathrm{DE}$ were not significantly different $(p>0.05)$.

The highest SGR was obtained at $40 \% \mathrm{CP}$ with $3000 \mathrm{DE}$ and the lowest at $25 \% \mathrm{CP}, 2800 \mathrm{DE}$. There was a significant increase in SGR from crude protein level to another with an exception at $35 \% \mathrm{CP}$ with $3000 \mathrm{DE}, 40 \%$ CP with $2800 \mathrm{DE}$. Except for the total weekly weight were the highest value was obtained at $40 \% \mathrm{CP}$ with 2800DE. Other parameters such as SGR, weekly weight gain (WWG) as well as PEWG had best value at $40 \%$ CP (3000DE) and the least weight 
Table 3. Effects of dietary protein and energy levels on the growth performance and feed utilization by post fingerlings of $C$. gariepinus

\begin{tabular}{|c|c|c|c|c|c|c|c|}
\hline Dietary treatments & TWG & RWG & SGR & PEWG & Feed intake & FCR & PER \\
\hline \multicolumn{8}{|l|}{2800 kcal/kg diet } \\
\hline $25 \%$ protein & $74.9^{\mathrm{cd}}$ & $1.15^{\mathrm{a}}$ & $7.67^{\mathrm{a}}$ & $23.18^{\mathrm{a}}$ & $1.78^{\mathrm{a}}$ & $1.53^{\mathrm{ab}}$ & $63.42^{c d}$ \\
\hline $30 \%$ protein & $12.57^{\mathrm{a}}$ & $1.30^{\mathrm{ab}}$ & $9.79^{\mathrm{ab}}$ & $25.10^{\mathrm{a}}$ & $2.70^{\mathrm{ab}}$ & $1.84^{\mathrm{b}}$ & $19.86^{\mathrm{ab}}$ \\
\hline $35 \%$ protein & $16.41^{\mathrm{bc}}$ & $1.71^{\mathrm{c}}$ & $12.92^{c}$ & $29.57^{\mathrm{b}}$ & $1.93^{\mathrm{ab}}$ & $1.66^{\mathrm{ab}}$ & $26.98^{\mathrm{b}}$ \\
\hline $40 \%$ protein & $16.54^{\mathrm{bc}}$ & $1.49^{b c}$ & $12.20^{\mathrm{bc}}$ & $23.48^{\mathrm{a}}$ & $1.55^{\mathrm{a}}$ & $1.71^{\mathrm{b}}$ & $78.79^{d}$ \\
\hline \multicolumn{8}{|l|}{$3000 \mathrm{kcal} / \mathrm{kg}$} \\
\hline $25 \%$ protein & $12.07^{\mathrm{a}}$ & $1.20^{\mathrm{ab}}$ & $9.80^{\mathrm{ab}}$ & $25.56^{\mathrm{a}}$ & $3.69^{\mathrm{ab}}$ & $1.94^{\mathrm{b}}$ & $10.37^{\mathrm{a}}$ \\
\hline $30 \%$ protein & $9.77^{\mathrm{a}}$ & $1.12^{\mathrm{a}}$ & $8.50^{\mathrm{a}}$ & $24.23^{\mathrm{a}}$ & $4.94^{\mathrm{b}}$ & $1.20^{\mathrm{a}}$ & $50.53^{\mathrm{c}}$ \\
\hline $35 \%$ protein & $15.93^{\mathrm{b}}$ & $1.50^{\mathrm{bc}}$ & $11.22^{\mathrm{bc}}$ & $24.51^{\mathrm{a}}$ & $2.30^{\mathrm{ab}}$ & $1.81^{\mathrm{b}}$ & $52.44^{c}$ \\
\hline $40 \%$ protein & $19.11^{\mathrm{C}}$ & $1.71^{\mathrm{c}}$ & $13.44^{\mathrm{C}}$ & $23.97^{\mathrm{a}}$ & $1.14^{\mathrm{a}}$ & $1.87^{\mathrm{D}}$ & $66.83^{\mathrm{cd}}$ \\
\hline SEM & 1.32 & 0.14 & 1.20 & 1.21 & 1.39 & 0.24 & 7.72 \\
\hline
\end{tabular}

gain recorded at $30 \% \mathrm{CP}$ (2800DE). PEWG level increased among various treatment except at $35 \% \mathrm{CP}(3000 \mathrm{DE})$ and $40 \% \mathrm{CP}(2800 \mathrm{DE})$.

\section{DISCUSSION}

Crude protein level of $40 \% \mathrm{CP}$ at a digestible energy level of $3000 \mathrm{Kcal} / \mathrm{kg}$ recorded the highest TWG, SGR and PEWG, this was Similar to the result recorded by [8] on the dietary protein requirement of giant river catfish, Sperata seenghala using diets of varying protein $(25,30$, 35 and $40 \%$ CP) and [9] on growth responses of Heterobranchus bidorsalis post fingerlings to different crude protein and digestible energy levels.

[10] Also worked on the optimum dietary protein levels and protein to energy ratios on growth and survival of juveniles spotted Babylon (Babylonia areolata) and recommended $35 \%$ crude protein and $4.0 \mathrm{Kcal} / \mathrm{g}$. This varying result in terms of growth rate reported in this study might be due to species of fish used [10].

The result from this study is also in accordance with the recommendation of crude protein levels by [11] where his result also suggested that protein requirement of fish to be above $35 \%$ and about $40 \%$. [12] also reported the protein requirement of C. gariepinus as $40 \%$ while [13] reported $45 \%$ for same species. [14] Reported similar result of $45 \%$ crude protein requirement for Hybrids of catfish. With the result of this study however, it is shown that increasing the dietary protein of fish to $45 \%$ did not have any statistical advantage, similar to the report of [15]. This is also in line with the report of [11] that excess protein does not support additional increase in growth performance but rather results in economic losses and deterioration of water quality.

The absolute energy requirement for catfish are unknown and estimate of the requirements have been determined by measuring the performance of catfish fed diets containing known energy levels. The energy requirement reported for catfish have generally been expressed as a ratio of digestible energy to crude protein. The DE:P ratio gotten from the recommended dietary protein level $(40 \% \mathrm{CP})$ at $3000 \mathrm{DE}$ which is 7.5 $\mathrm{Kcal} / \mathrm{g}$ actually fall in the range reported by [16] of 7.4-12.0 Kcal/g, similar with report of Mississipi State University which indicated that a $D E: P$ ratio of $7.3-10.0 \mathrm{Kcal} / \mathrm{g}$ is adequate for use in commercial catfish diets. [17]. Ratios above these range may lead to increased fat deposition, while at lower DE:P ratio, the fish will grow at slower rate.

\section{CONCLUSION}

Crude protein level of $40 \%$ at DE level of 3000 $\mathrm{Kcal} / \mathrm{kg}$ in the diet of C. gariepinus post fingerlings resulted in optimum growth in the present work.

\section{COMPETING INTERESTS}

Authors have declared that no competing interests exist.

\section{REFERENCES}

1. Adewolu MA, Adoti AJ. Effect of mixed feeding schedules with varying dietary crude protein levels on the growth and feed utilization of Clarias gariepinus 
(Burchell, 1822) fingerlings. Journal of Fisheries and Aquatic Sciences. 2010;5: 304-310.

2. Hixson SM. Fish nutrition and current issues in aquaculture: The balance in providing safe and nutritious seafood, in an environmentally sustainable manner. Journal of Aquaculture Research and Development. 2014;5(3):2-10.

3. Gabriel UU, Akinrotimi OA, Bekibele DO, Onunkwo DN, Anyanwu PE. Locally produced fish feed: Potentials for aquaculture development in Sub-Saharan Africa. African Journal of Agricultural Research. 2007;2(7):287-295.

4. Shiau SY, Huang SL. Influene of varying energy levels with two protein concentrations in diets for hybrid tilapia (Oreochromis niloticusx O. aureus) reared in seawater. Aquaculture. 1990;91:143152.

5. Owodeinde FG, Ndimele PE. Survival, growth and feed utilization of two clariid catfish (Clarias gariepinus, Burchell, 1822 and Heterobranchus bidorsalis, Geoffrey, 1809) and their reciprocal hybrids. Journal of Applied Ichthyology. 2011;27:12491253.

6. Martinez-Palacios PCA, Harfush-Melendez M, Chavez-Sandchez C, Ross LG. The optimum dietary protein level for the Mexican cichlid, Cichlasoma urophthalmus (Gunther): A comparison of estimates derived from experiments using fixed-rate feeding and satiation feeding: Aquaculture Nutrition. 1996;2(1):11-21.

7. AOAC. Official methods of analysis $\left(15^{\text {th }}\right.$ edition) of the Association of Official Analytical Chemist (A.O.A.C) Virginia. 1990;1298.

8. Muhammad RA, Muhammad A, Muhammad FK, Naqvi SMHM, Shamim A. Dietary protein requirement of Giant River Catfish, Sperata seenghala (Sykes), determined using diets of varying protein level. Pakistan Journal of Nutrition. 2004;13(3):151-156.

9. Aliu BS, Umukoro E, Esume AC. Growth response of Heterobranchus bidorsalis post fingerlings fed various dietary protein and energy levels. International Journal of Agriculture and Environmental Research. 2016;2(6):1847-1857.

10. Chaitanawisuti N, Rodruang R, Piyatiratitivorakul S. Optimum dietary protein levels and protein to energy ratios on growth and survival of juveniles spotted Babylon (Babylonia areolata) under the recirculating seawater conditions. International Journal of Fisheries and Aquaculture. 2010;2(2):58-63.

11. Nwanna LC, Omojola I, Nwanna E, Abiodun E. Effect of protein deficient diets on the growth and carcass protein ash ratio of African catfish, Clarias gariepinus (Burchell, 1822). Journal of Applied Science and Environmental Management. 2014;18(3):537-541.

12. Fagbenro O, Balogun A, Anyanwu C. Optimum dietary protein level of Heterobranchus bidorsalis fed compounded diet. Nigeria Journal of Applied Fisheries Hydrobiology. 1992;1: 41-45.

13. Anyanwu C. Protein requirements of African catfish (Clarias gariepinus) cultivated in glass tans. Journal of Applied Tropical Agriculture. 2000;5:10-16.

14. Adebayo T. Dietary protein level and feeding rate for hybrid Clariid catfish, Clarias gariepinus $x$ Heterobranchus bidorsalis, in homestead tanks. Journal of Applied Aquaculture. 2005;9(1):97-106.

15. Oishi CA, Nwanna Cl, Filho MP. Optimum dietary protein requirements for Amazonian tambaqui, Colossoma macropomum Cuvier, 1818, fed fish meal free diets. Acta Amazonica. 2010;40(4): 757-762.

16. Robinson EH, Li MH. Catfish protein nutrition. Revised. Mississippi Agricultural and Forestry Experiment Station Bulletin 1159. Mississippi State University. 2007; 18.

17. Robinson $\mathrm{EH}$, Li MH. A practical guide to nutrition, feeds and feeding: Revised. Bulletin 1041, Mississippi Agricultural and Forestry Experiment Station. 1996;26.

(c) 2017 Aliu and Otuagomah; This is an Open Access article distributed under the terms of the Creative Commons Attribution License (http://creativecommons.org/licenses/by/4.0), which permits unrestricted use, distribution, and reproduction in any medium, provided the original work is properly cited.

Peer-review history:

The peer review history for this paper can be accessed here: http://sciencedomain.org/review-history/18196 